JOURNAL

of Health Inequalities

\title{
One hundred years of health in Poland
}

\author{
Witold A. Zatoński \\ Health Promotion Foundation, Nadarzyn, Poland \\ European Observatory of Health Inequalities, the President Stanisław Wojciechowski State University of Applied Sciences \\ in Kalisz, Poland
}

\begin{abstract}
Life expectancy is the best synthetic indicator for measuring the improvement or deterioration of a country's health across time. This article charts the life expectancy trends, and their underlying factors, in Poland in the last one hundred years. The process of health gain in Poland has seen much fluctuation. Periods of health convergency with Western Europe have been intertwined with periods of divergency and crisis. The social and economic watershed of 1989 has been followed by a rapid improvement in health indicators. However, the last fifteen years have seen a stalling of the health growth in Poland.
\end{abstract}

KEY WORDS: life expectancy, epidemiological transition, Poland, public health, tobacco control, alcohol diseases, diet.

ADDRESS FOR CORRESPONDENCE: Witold A. Zatoński, Health Promotion Foundation, 51 Mszczonowska St., 05-830 Nadarzyn, Poland, phone +48 2237800 22, e-mail: wazatonski@promocjazdrowia.pl

Supplementary materials (slides) are available in Webappendix 2 at the journal's website: https://www.termedia.pl/Journal/Journal_of_ Health_Inequalities-100.

\section{INTRODUCTION}

The last century has seen a rapid improvement of health indicators around the world. Life expectancy has been historically the best and most useful measure for charting health developments across time and space. This paper analyses the health trends in Poland in the last century through the lens of life expectancy.

After World War II we have seen a global convergence of life expectancy trends (see slide 6 in Webappendix 2). In most high-income, politically and economically stable countries a steady increase in life expectancy has been observed. In Poland, and the neighbouring countries of Central and Eastern Europe, the trends in life expectancy have seen much fluctuation. Periods of quick health growth have been intertwined with periods of stalling health improvement, or even its freezing (see slide 6 in Webappendix 2).

\section{HUMAN DEVELOPMENT INDEX}

Since the early 1990s the United Nations have been using a synthetic measure called the Human Development Index (HDI) to classify the degree of socio-eco- nomic development and quality of life in different countries. The HDI allows to make comparisons across countries, and track development through time. The index is composed of three elements - per capita Gross Domestic Income, a measure of education combining average adult years of schooling with expected years of schooling for children, and life expectancy (see slide 6 in Webappendix 2).

In the hundred years since Poland regained its independence in 1918 the country has experienced significant improvement in economic and educational attainment [1]. The Polish economists Paweł Bukowski and Wojciech Paczos estimated that in this period Polish GDP rose from EUR 4,000 to EUR 24,000 [2]. They argue that 'despite wars and crises we are today six times wealthier than our great-grandparents were in 1918 [1]. Most striking are the last three decades, in which Poland developed not only without interruption, but also significantly faster than the West' $[1,2]$.

Similar trends were observed in measures of educational development $[3,4]$. In the last century Poland underwent an educational revolution. In 1919 illiteracy 
was common in Poland, especially in rural areas. The development of public education after World War I, and especially its expansion after World War II allowed all citizens access to at least basic secondary education. Since 1990 the educational development of the Polish population has been proceeding apace. Only $10 \%$ of the population - around 2.5 million Poles, have primary education, with the rest of the population having completed secondary school or higher. Between 1995 and 2009 the share of people aged 25-64 with higher education increased from $9.7 \%$ to $21.2 \%$. Today, the number of university-educated Poles stands at over 5 million. Nonetheless, Poland is still far from Canada and the United States, where $48 \%$ and $40 \%$ of citizens, respectively, have higher education [3].

Life expectancy is the final component of the HDI. It is also the best synthetic indicator for measuring the improvement or deterioration of a country's health across time. Life expectancy forms the basis of the analysis of health in Poland conducted in this article. In Poland, annual collected data on life expectancy are only available since 1950 (the data from earlier periods is fragmentary) [5-7].

In the years 1990-2000 the Polish HDI was growing by about $1 \%$ every year, which was one of the quickest increases of this indicator in the world, and Poland moved up by 5 positions. In the next periods analysed, 2000-2010 and 2010-2017, the pace of HDI increase declined by half. In 2017 Poland was on the $33^{\text {rd }}$ position of the global ranking of HDI [8].

\section{HEALTH BEFORE THE WORLD WAR II}

The scale and rate of health improvement in the $20^{\text {th }}$ century is without precedent in human history. In the period of one hundred years in many countries life expectancy doubled, from under 35 to over 70 years globally. However, while in most countries of Western Europe this growth has occurred in a harmonious, sustainable manner, in much of Central and Eastern Europe, including Poland, it was characterised by leaps, plunges, and fluctuations ${ }^{1}[9,10]$.

Highly developed countries of Western Europe have seen their life expectancy levels increase steadily from the end of the $19^{\text {th }}$ century. Between 1870 and 1880 average life expectancy levels stood at 37 years in Germany, 43 years in England and Wales, and 47 years in Sweden. By the break of the 1920s and 1930s it already stood at 61 years in Germany, England and Wales, and at over 64 years in Sweden [10-12].

This was in contrast with the state of health in the Polish population during and after the World War I. Between August and October 1918 Poland experienced its largest epidemic of infectious diseases as the Spanish flu pandemic took a heavy toll on the country $[13,14]$.
By 1927 the average life expectancy in Poland was still at a dramatically low level and was estimated to be 46 years. As much as $40 \%$ of newborns did not live past the age of 5 . In comparison, in Sweden in 1920 this figure stood at $15 \%$. Throughout the interwar period Poland failed to cope with infectious diseases, in particular typhoid, tuberculosis, and infectious diseases of children. Life expectancy in Poland still stood at under 50 years in 1939 , on average 10-15 years below the levels of developed European states [6, 11, 12].

The World War II exacerbated the situation [5]. The country's infrastructure was in ruins, and the sanitary and hygienic state of the Polish population, already low before the war, deteriorated further. New epidemics of infectious diseases were breaking out. It is estimated that in the catastrophic period between 1939 and 1945 life expectancy in Poland dropped by $20-25$ years. The health situation in 1946 was described by the reporter Junta Połczyński, who after a few weeks spent in Poland wrote about 'an epidemic of infectious diseases reminiscent of the Middle Ages' [15].

The first reliable epidemiological estimates after World War II, carried out in 1950, summarised the health situation in Poland. Infant mortality was estimated at 110-120 deaths per 1000 live births, and 33\% of children did not live to the age of 5 . In contrast, in Sweden and England infant mortality stood at 20/1000 live births, and $5 \%$ of children did not live to the age of 5. Maternal mortality was also very high in Poland and stood at 100 deaths/1000 births $[5,11,12]$.

\section{EPIDEMIOLOGICAL TRANSITION}

The epidemiological transition in Poland began in earnest only in the 1950s, so almost one hundred years later than in Sweden or Great Britain. The starting point was very low and not dissimilar to the health situation in some Western European countries in the $19^{\text {th }}$ century. However, the improvement of the health state in Poland in the decades following World War II proceeded rapidly $[5,11]$.

The dominance of the Soviet Union over Central and Eastern European after World War II also influenced the shape of the health doctrine in the region. The 'universal health system', or so-called 'Semashko model' (named after a Minister of Health in Lenin's government) was also introduced in Poland, leading to fundamental change in health policy. The Semashko model ensured every citizen had access to free medical care. It was characterised by the phenomenon of 'medicalisation of health'. The term 'medicalisation' in Poland is often perceived positively and understood as describing easy access to medicine, doctors, hospital beds. The debates about the negative societal impact of overmedicalisation, ongoing in the Western world since the 1960s, are still sparse in Poland even today $[11,16-18]$. 
Developing a system of combatting infectious diseases was a central strategic priority of the Semashko model. In order to contain the infectious disease epidemic in Poland in 1954 the State Sanitary Inspectorate was created. At the same time sanitary-epidemiological stations were established, conducting vaccination campaigns, but also educating the population about the importance of vaccination and hygiene. Another important element of the Semashko model was the creation of an effective system of maternal and childcare. The improvement in health was also shaped by the increasing levels of female education and of their health competencies. Within a short period, over $90 \%$ of Polish children were included in vaccination prophylaxis [11].

A spectacular symbol of the involvement of Polish communist authorities with the fight against infectious diseases was Poland's pioneering role in tackling polio [19]. In the 1950s every year thousands of children in Poland encountered the disease. In the late 1950s Hilary Koprowski, a Polish virologist working in the United States, and the inventor of the first polio vaccine, obtained 9 million doses of the vaccine for Poland. In autumn 1959 Poland became one of the first countries in the world to embark on mass polio vaccination, and the number of cases of the disease declined to just a few dozen in the early 1960s [11].

A result of these changes was quickly declining infant and child mortality (see slide 6 in Webappendix 2). Within 10 years infant mortality rates in Poland decreased by half (from 109/1000 live births in 1950 to 55/1000 live births in 1960). By 1970 infant mortality in Poland stood at 30/1000 live births. At the same time in West Germany it was 23/1000, in Austria 26/1000, in Italy 29/1000, and in Portugal 53/1000. Mortality before the age of 5 in Poland declined from 33\% in 1950 to $7 \%$. Twenty-five years after the end of World War II infant and child mortality in Poland reached a good, European level. The same applied to maternal mortality, which declined from $100 / 100000$ live births to $30 / 100000$ in 1970. Mortality due to infectious diseases also rapidly decreased, for example among men it fell from 99/100 000 in 1963 to 20/100 000 in 1985 $[11,12,16-18]$.

All of these positive developments led to a leap in life expectancy in Poland in both sexes. In the 1950s life expectancy in Poland grew by 9 years, while in West Germany the growth was only 2.5 years. In the late $1960 \mathrm{~s}$ life expectancy in Poland, at 70 years, was only 1-2 years lower than in highly developed Western European countries (in England and Wales it was 72 years, in Western Germany 71 years). The health gap between Western Europe and Poland was almost closed [16-18, 20-22].

\section{ERA OF NON-INFECTIOUS CHRONIC DISEASES}

After World War II, just as the epidemiological transition was taking place in Poland, the main public health problem in developed countries were increasingly chronic diseases. Lung cancer by the late 1940s became the number one killer in countries such as the UK. Northern European countries, such as Finland or the UK, saw rapidly increasing cardiovascular disease morbidity and mortality. In France and Italy liver cirrhosis and laryngeal cancer reached epidemic levels. All of these were leading to the changing paradigm of health policy and medicine in many high-income countries [16, 22-25].

As a result, in Western Europe in the 1960s and 1970 a new philosophy of public health was increasingly adopted, the main tenet of which was that health policy must be realised by the entire government and all its ministries - especially the Ministry of Finance - and not just the Ministry of Health. This so-called 'Health in All Policies' approach was successfully carried out by countries such as Finland, which from a nation with poor health in the 1960s became one of the European public health leaders. Another example is the United Kingdom, which was traditionally a tobacco trade, sales, and consumption powerhouse (in the late 1940 s around $80 \%$ of adult British men smoked cigarettes). The UK government took a comprehensive approach to tackling smoking, especially using economic and educational tools. Cigarettes were heavily taxed, and the UK became one of the countries with highest cigarette prices in Europe. As a result of these measures lung cancer rates were reversed and decreased threefold. British scientists estimate that half of the decline in cardiovascular disease morbidity was also due to the rapid decline of smoking prevalence [7, 23, 26-29].

This shift in thinking about health (broadening it from just focusing on curative medicine), campaigns to build health competencies of the population, popularising healthy lifestyles, and the close participation of state and society in public health programmes led to rapid health gains in Western European, democratic countries. In contrast, in Poland and neighbouring communist countries, the period between 1960 and 1990 saw numerous developments deleterious to health. Alcohol consumption doubled. Tobacco consumption per capita grew from 1065 to 2648 cigarettes annually, in the late 1980s reaching the highest level in the world. Consumption of butter and full-fat milk was also beating world records. Consumption of read, highly processed meat, especially pork, as well as sugar, was growing. A steady increase in calories (in the 1970s and 1980s higher than in countries of western Europe), coincided with a decrease in physical activity. Levels of overweight, obesity and diabetes rose. This applied to inhabitants of cities, but was even more prevalent among inhabitants of villages, also children [17, 18, 29-34].

All of these processes resulted in dramatic health consequences. Between the early 1960s and early 1990s a very unusual phenomenon in peace time was observed in Poland - every year the mortality of young- and middle-aged adults, especially men, was increasing. Life expectancy at the age of 20 was decreasing, while stroke mortality 
was increasing. Among Polish men lung cancer morbidity skyrocketed, reaching the highest levels in the world, especially among young- and middle-aged adults. Liver cirrhosis morbidity also increased. Almost one in five men died prematurely due to injuries. All of these negative trends were happening at the same time as the number of doctors and hospital beds in Poland was steadily growing - in 1990 it was higher than the OECD average [16, 35-40].

By the late 1980s the health of Poles was in a catastrophic state. Premature mortality in middle age, mortality due to lung cancer and other tobacco-related cancers, liver cirrhosis, CVD, and sudden deaths due to external causes (accidents, injuries, poisonings) reached in Poland some of the highest levels in the world. This epidemic of man-made diseases became one of the greatest challenges facing the country as the communist system was nearing to collapse. According to WHO estimates in 1990 a 15-year old boy in Poland had a lower probability of living to the age of 60 than his peers in China, Latin America, or India [11, 36, 41].

\section{THE HEALTH MIRACLE: DEMOCRACY IS HEALTHIER}

When at the end of the 1980s democratic transformation and market economy begun in Poland, health of adult Poles was in catastrophic shape and health prognoses were poor [41]. After a short period of health perturbations (1988-1991) resulting from political transition processes, completely unexpectedly a health improvement begun in Poland. Almost all health indicators started to improve. In years 1991-2001 infant mortality rates declined from 15.0/1000 to 7.7/1000 live births. For the first time in 30 years the negative trends of adult premature mortality have been reversed. All-cause mortality rates decreased in all age groups, especially in young and middle-aged adults. Mortality in men in age group 20-64 years declined from 38\% to 30\% between 1991 and 2001, and at the same time CVD mortality declined dramatically in both sexes. Among young adults aged 20-44 CVD mortality declined by $50 \%$, in middle age (45-64) by $40 \%$, and in age groups $65+$ by $30 \%$ [12, 16-18, 42-44] (see as well Sir R. Doll and R. Peto box).

For the first time since World War II the improvement of health indicators concerned both sexes, although it was faster in men. The decline in adult male premature mortality between 1991 and 2002 resulted from decreases in three groups of causes of death: cardiovascular diseases (decrease of around 40\%), cancer - especially lung cancer and other tobacco-related neoplasms (12\%), and injuries (around 30\%). At the same time life expectancy increased

Sir Richard Doll and Sir Richard Peto - founders of modern health science, epidemiology, and public health. They participated in the development of Polish epidemiology and visited Poland on numerous occasions. They also wrote the introduction to a seminal essay on health in Poland: "Evolution of health" (1996) 2 - the full text is quoted below:

The difference in premature mortality among people of middle age between the countries of western and eastern Europe, especially Poland, has a number of causes. At current death rates, about one in five of all Polish men will be killed by tobacco before reaching their $70^{\text {th }}$ birthday. Prolonged cigarette use, more than any other single factor, accounts for the remarkable deterioration in the health situation of the Poles that took place between 1965 and 1990. And, the recent increase in female cigarette use means that, on current smoking patterns, tobacco will eventually become a major cause of death for Polish women, as well as for Polish men. But, as Professor Zatoński shows in his wide-ranging survey of mortality trends, although tobacco is the biggest single cause of premature death in Poland, there are also other important causes, and the news is not all bad.

Eighty years ago, Poland reclaimed its status as an independent nation after 150 years of servitude but found itself with very high mortality rates. In the years after 1918 Poland suffered not only times of famine and war but also large epidemics of infectious diseases, such that only about one-half of all newborn infants could be expected to survive into middle age. (Indeed, during the 1930s $14 \%$ died in their very first year of life.) In terms of health the greatest achievement this century, in Poland as elsewhere, has been the enormous reduction in childhood and early adult mortality. Nowadays, only $4 \%$ of Polish infants can be expected to die before their $35^{\text {th }}$ birthday. Even in middle age there has been some important progress: tuberculosis (which used to be one of the chief causes of death in Poland) has been controlled and, very recently, the steady increase in cardiac deaths has ceased, perhaps because of dietary change. After 1989 most of the animal fat in the Polish diet from sources such as butter was, for purely economic reasons, replaced by non-animal fat from sources such as vegetable oil, and during the early 1990 s there was a sudden decrease of about one-quarter in heart disease deaths in early middle age. Is this an accidental demonstration, on a nationwide scale, of the preventive potential of dietary change? Professor Zatoński believes so, and bis arguments deserve serious scrutiny.

But, although some trends are favourable, the overall picture in Poland, as elsewhere in Central Europe in the 1990s, is of a vast epidemic of unnecessary deaths in middle age. At present, half of all Polish men die before age 70, while only a quarter of Swedish men do so. Most but not all of this difference is due to tobacco, and Polish death rates could be substantially reduced by the continuation of dietary change, by the appropriately widespread use of cost-effective treatments for disease and, above all, by effective action against tobacco. By making the evidence so clearly available, in this as in his many other publications, Professor Zatoński shows that about half the premature deaths in Poland could be avoided by taking existing knowledge appropriately seriously.

Richard Peto, FRS, Richard Doll, FRS, University of Oxford, UK (1996)

2Zatoński W. Evolution of health in Poland since 1988. Maria Sklodowska-Curie Cancer Center and Institute of Oncology, Warsaw 1996. 
Statement from Prof. Grzegorz Opolski, one of the leaders of Polish cardiology, for the medical journal "Puls Medycyny" in 2017.

In the last two decades the treatment of patients with acute myocardial infarction by primary percutaneous coronary angioplasty has become a standard and improved the access to invasive cardiology and electrotherapy, such as the implantation of cardioverters-defibrillators and ablation. Poland became one of the European Union leaders in the invasive treatment of acute coronary syndromes. This resulted in a threefold decrease in mortality after myocardial infarction. The success of cardiology is the result of group action - a strong, united cardiologic community and a good understanding of the problem by the decision-makers. It is obvious that the introduction in 2003 of the National Programme of Prevention and Treatment of Cardiovascular Diseases - POLKARD, played a key role in this, alongside the acceptance of cardiology as a deficit specialties.

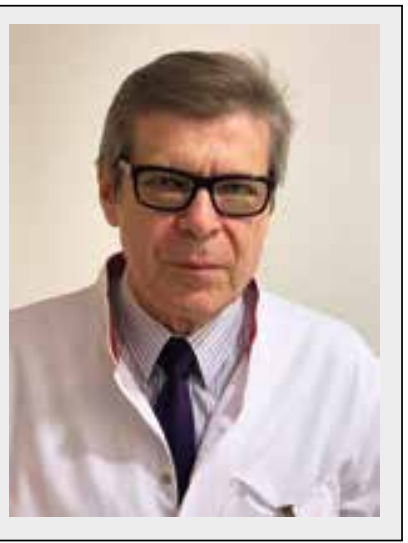

by 4 years in men and 3 years in women. Health improvement in the 1990s concerned everybody, regardless of sex, age, education and place of living. After the introduction of democratic system and market economy in Poland health became the most important value. Both government and citizens considered health as one of the most important elements of wellbeing [16, 22, 45, 46].

After the political breakthrough of the late 1980s, few fundamental favourable circumstances occurred in public health. First, an anti-tobacco law was drafted and introduced in 1995. It was a baseline for the preparation of a national tobacco control programme, which was evaluated by the government and accepted by the Parliament each year. Health education campaigns begun on large scale. Cyclical intervention efforts were conducted, e.g. the national campaign "Quit smoking together"/ "Great Polish smoke-out". This campaign was recognised as the largest and most effective public health action in Europe at the time.

In the subsequent years, Parliament introduced national governmental programmes controlling cancer and cardiovascular diseases in Poland with substantial financial sources from national budget dedicated to their realisation $[47,48]$. Substantial funds were also allocated to primary and secondary prevention efforts. Another important element of health building was the rapid change in diet structure resulting from the introduction of market economy and new availability of a variety of food products. This led to a change in patterns of fat consumption (levelling out of deficiency of n-3 fatty acids, levelling out of consumption of vegetable oils, decreasing consumption of animal fats), but also the increase in availability of fruits and vegetables, as these products became relatively cheap and available all year. Finally, the market economy enabled access to modern medicines and medical technologies. Especially the cardiac community exploited these new opportunities and introduced a range of effective cardiosurgical treatment programmes in Poland [16-18, 40, 49-51] (see Prof. G. Opolski box).

By the end of the $20^{\text {th }}$ century it seemed that Poland had followed other Western, high-income countries on a path of stable health improvement. In fact, the health gain in Poland in 1990s was one of the most rapid in Europe and adult premature mortality (before 65 years of age) decreased substantially $[16,18,22,52-55]$. The health gap between Poland and the West seemed to be closing.

\section{HEALTH DEVELOPMENT IN POLAND IN THE $21^{\text {ST }}$ CENTURY}

In the beginning of the $21^{\text {st }}$ century Poland was recognised as one of the public health leaders in the world $[18,22,25,44,54]$. The Polish anti-tobacco law was called by the WHO an example to the rest of the world. Polish health warnings on cigarette packages were the largest in the world and the Polish standards were later adopted by the European Union. Poland also introduced a ban on tobacco advertisement [25]. The Polish Prime Minister and Minister of Health were awarded by the Director-General of the WHO, Gro Harlem Brundtland, for their achievements in tobacco control in Poland. The Director of WHO Regional Office for Europe in Copenhagen, Marc Danzon, organised in 2001 in Warsaw the WHO European Health Ministers Meeting devoted to coordination of anti-tobacco activities in Europe (see Photo 1). Poland was one of the initiators and took part in preparing the first health convention of United Nations - the World Health Organization (WHO)

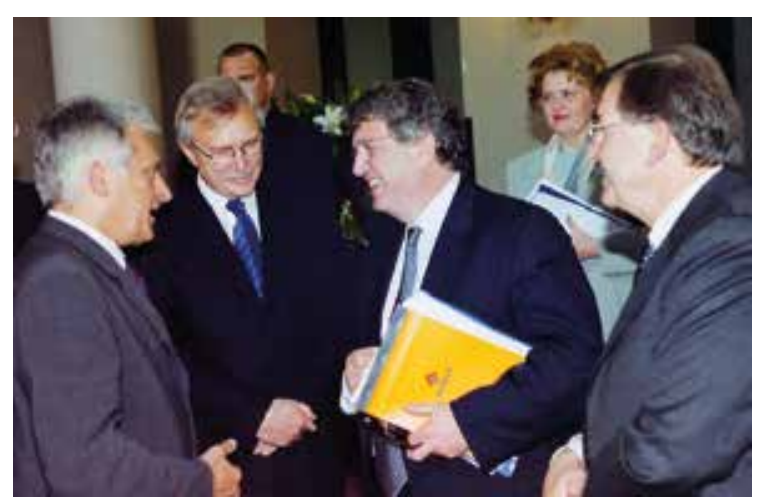

PHOTO 1. From left to right: Polish Prime Minister Jerzy Buzek, Health Minister Prof. Grzegorz Opala, WHO Director Marc Danzon, Prof. W. Zatoński, Warsaw 2001 


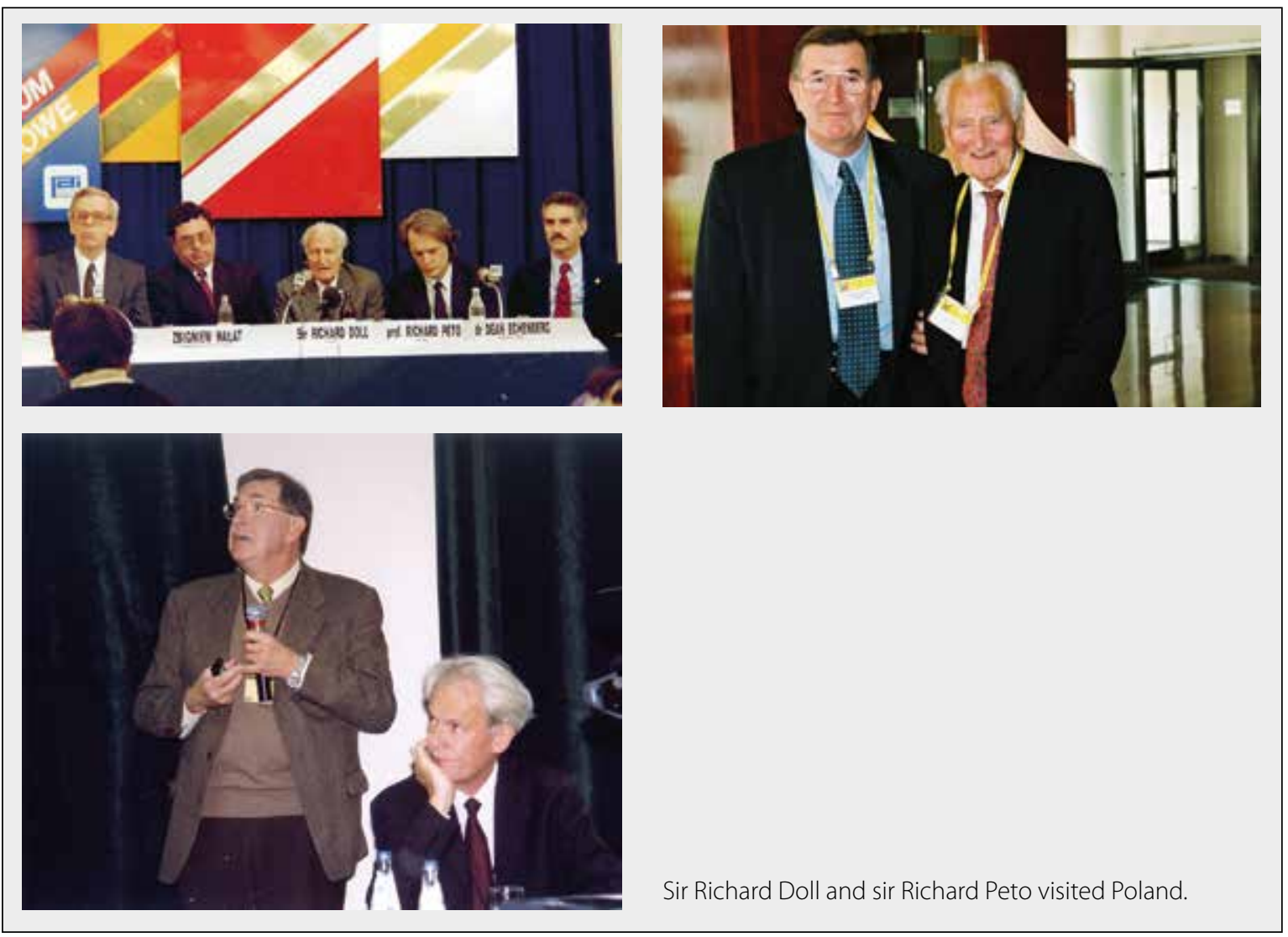

Framework Convention on Tobacco Control (FCTC) [56]. A series of papers analysing the pace of decline in smoking prevalence in the world between 1970 and 2015 was published recently [57-59]. In these publications Poland is included into the group of countries with the most rapid pace of decline in smoking prevalence, from the highest level in the world in 1980 (see slides 18, 19, 20 in Webappendix 2) $[25,53,54,57,58,60]$.

In August 2002 the Polish government decided to decrease the excise tax for spirit products (vodka) in Poland by $30 \%$ [61]. This led to an immediate, rapid increase in alcohol consumption [32, 55, 61, 62]. Registered annual vodka consumption per capita calculated per $100 \%$ of spirit in years $2003-2008$ doubled from 1.7 to 3.4 litre (see slide 25 in Webappendix 2). In the years 2003-2017 consumption of alcohol (especially vodka and beer) increased in Poland from 7 to almost 10 litres of pure alcohol per capita [63]. By the year 2019 Poland reached the highest level of alcohol consumption in history. This increase in alcohol consumption resulted in a growing disease burden [64, 65]. Analysis by Moskalewicz and Wieczorek documented the increase in diagnosed alcohol psychoses by $1 / 3$ in years 2003-2008 $[32,66]$. Epidemiological analyses of mortality showed annual increase in alcohol-attributed mortality since 2003 (see slide 25 in Webappendix 2). At the same time, Poland experienced a freezing in the decline in adult premature mortality (20-64 years) [55]. The increase in life expectancy in both men and women started to slow down (see slide 29, 30 in Webappendix 2). Since 2013, Poland has experienced a freezing of increase in life expectancy in both sexes (2013 - 77 years, 2014 77.5 years, 2015 - 77.5 years, 2016 - 77.81 years) [10].

The epidemiological situation that we have been observing in the recent years in Poland should be the cause of immediate public health concern and action. Interdisciplinary research is needed, involving epidemiologists, economists, sociologists and other scientists, to assess the social and economic causes of abovementioned phenomena and spurring immediate political and regulatory action.

\section{CONCLUSIONS}

Poland remains a country of relatively poor health, which stands in contrast with the rapid improvement in wealth and education which we have observed in the last decades. The health gain in Poland has not been stable and has been characterised by significant fluctuations $[11,12,16-18,67,68]$. It seems that one of the underlying factors for this is the still low level of health competencies among the Polish population. Health education, changing health behaviours, progressive health policy conducted by the authorities, a health-in-all-policies approach of the government - only with these approaches Poland can return to a sustainable trend of health improvement $[69,70]$. 
Poland in the last decades has been a good example of both effective, evidence-and-science based health policy conducted by the government, as well as of catastrophic public health blunders committed by decision makers $[61,63,71,72]$.

After World War II an example of the positive actions was the ability to rapidly tackle the high levels of infectious diseases and infant and child mortality. Similarly, in the 1990s primary and secondary prevention, as well as improvements in treatment, paved the way for a cardiovascular revolution in Poland, reducing the CVD morbidity and mortality at a very quick pace $[17,18,22]$. Modern preventive and clinical cardiology were created. However, the greatest success in the last three decades was the ability to reverse the tobacco epidemic and the resulting toll of disease and mortality. Recent epidemiological analyses show that the decrease in smoking prevalence and cigarette consumption in Poland between 1990 and 2015 was among the fastest in the world [5759]. Poland became a leader in tobacco-related disease control. The risk of tobacco-related diseases halved. The ability to achieve this success was to a large extent possible thanks to Polish oncology. The halving of lung cancer morbidity in certain age groups, for instance among young and middle-aged man, was one of the greatest successes of Polish medicine.

On the other hand, in the last decades the Polish policymakers exposed the population to a gigantic natural experiment. In 2002 the excise tax on vodka products was decreased by $30 \%$ and the laws regulating beer marketing have been liberalised [71]. This led to a rapid increase in alcohol consumption from circa 7 to circa 10 litres of pure alcohol per capita. The effects of this are the stalling (since 2003), and then the freezing (since 2013) of the increase in life expectancy in Poland. An immediate return of good practice public health activity, which has existed in Poland in the 1990s, is necessary. Without this further economic and social development of the country will be impossible.

\section{ACKNOWLEDGEMENTS}

The author would like to thank Kinga Janik-Koncewicz, Katarzyna Rosik, Iwona Młoźniak, and Dr Mateusz Zatoński for their assistance in preparing the article.

\section{DISCLOSURE}

The author declares no conflict of interest.

\section{References}

1. Bielak R, Ambroch M, Czermak G, et al. 100 lat Polski w liczbach 1918-2018. Główny Urząd Statystyczny, Departament Opracowań Statystycznych, Warszawa 2018. Available from: https:// stat.gov.pl/files/gfx/portalinformacyjny/pl/defaultaktualnosci/5501/30/1/1/100_lat_polski_w_liczbach_1918-2018.pdf (accessed: 15 May 2019)

2. Bukowski P, Paczos W. Złote dekady niepodległości [Golden Decades of Independence]. Rzeczpospolita, 09.11.2018: 37. Avail- able from: http://archiwum.rp.pl/artykul/1390020-Zlote-dekady-niepodleglosci.html (accessed: 15 May 2019).

3. Eurostat. Population aged $25-64$ by educational attainment level, sex and NUTS 2 regions (\%). Available from: https://ec.europa.eu/ eurostat/databrowser/product/page/TGS00109 (accessed: 15 May 2019).

4. Eurostat. Population by educational attainment level, sex and age (\%) - main indicators. Available from: http://appsso.eurostat.ec.europa.eu/nui/show.do?dataset=edat_lfse_03\&lang=en (accessed: 15 May 2019).

5. Holzer JZ. Demografia; 231-270; Rocznik Statystyczny 1955. Warszawa 1955; 57.

6. Mackenbach JP, Looman CW. Life expectancy and national income in Europe, 1990-2008: an update of Preston's analysis. Int J Epidemiol 2013; 42: 1100-1110.

7. Ståhl T, Wismar M, Ollila E, et al. Health in All Policies: Prospect and potentials. Ministry of Social Affairs and Health, Helsinki 2006; 1-269.

8. Jahan S. Human Development Indices and Indicators: 2018 Statistical Update. United Nations Development Programme, New York 2018. Available from: http://hdr.undp.org/sites/default/files/2018_ summary_human_development_statistical_update_en.pdf (accessed: 15 May 2019).

9. Riley JC. Estimates of regional and global life expectancy, 18002001. Population and Development Review 2005; 31: 537-543.

10. WHO Mortality Database. Health statistic and information systems, 2014. Available from: http://www.who.int/healthinfo/mortality_data/en/ (accessed: 15 May 2019).

11. Zatoński WA, Zatoński M. Health in the Polish People’s Republic. J Health Inequal 2016; 2: 7-16.

12. Zatoński WA, Zatoński M. Sytuacja zdrowotna (1945-1989). Dzieje medycyny w Polsce, tom 3. Lata 1944-1989. Noszczyk W (ed.). Wydawnictwo Lekarskie PZWL, Warszawa 2016; 77-86.

13. Chwalba A. 1919. Pierwszy rok wolności [The First Year of Freedom]. Wydawnictwo Czarne, Wołowiec 2019.

14. Wypustek A. Przyczynek do historii życia codziennego w Starożytności. Imperium szamba, ścieku i wychodka [The Foundation of History of Daily Life in Antiquity]. Wydawnictwo Naukowe Sub Lupa, Warszawa 2018.

15. Janta-Połczyński A. Wracam z Polski 1948. In: Antologia polskiego reportażu XX wieku. Tom 1. Szczygieł M (ed.). Wołowiec 2014: 610 .

16. Zatoński WA, Zatoński M. Democracy is healthier - health in Poland in the late 1980s and 1990s. J Health Inequal 2016; 2: 17-24.

17. Zatoński W and the HEM project team. Closing the health gap in European Union. The Maria Skłodowska-Curie Memorial Cancer Center and Institute of Oncology, Warsaw 2008.

18. Zatoński WA, and the HEM project team. Epidemiological analysis of health situation development in Europe and its causes until 1990. Ann Agric Environ Med 2011; 18: 194-202.

19. Williams G. Paralysed with Fear: The story of polio. London 2013; 218-247.

20. Zatoński W. Sytuacja zdrowotna w Polsce na tle krajów Europy Środkowej i Wschodniej. In: Perspektywy epidemiologii w Polsce - bilans otwarcia na XXI wiek. Brzeziński ZJ (ed.). Komisja Epidemiologii Komitetu Epidemiologii i Zdrowia Publicznego Wyd- 
ziału Nauk Medycznych Polskiej Akademii Nauk, Warszawa 2001; 15-30.

21. Zatoński WA, Aaro LE, Samdal O, Mazur J. Smoking- or nicotine-free generation, or both? What should be the public health priority? J Health Inequal 2016; 2: 105-108.

22. Zatoński WA, Bhala N. Changing trends of diseases in Eastern Europe: Closing the gap. Public Health 2012; 126: 248-252.

23. Puska P. From Framingham to North Karelia: from descriptive epidemiology to public health action. Prog Cardiovasc Dis 2010; 53 $15-20$.

24. White A. An examination of the association between premature mortality and life expectancy among men in Europe. Eur J Public Health 2014; 24: 673-679.

25. Zatoński M. State, society, and the politics of smoking in Poland, during and after communism (1960-2000). PhD thesis London School of Hygiene and Tropical Medicine, 2019. Available from: https://researchonline.lshtm.ac.uk/4653914/2/2019_PHP_PhD_ Zatonski_M_images_redacted.pdf(accessed: 25 May 2019).

26. Dokova KG, Stoeva KJ, Kirov PI, et al. Public understanding of the causes of high stroke risk in northeast Bulgaria. Eur J Public Health 2005; 15: 313-316.

27. Doll R, Hill AB. Smoking and carcinoma of the lung; preliminary report. Br Med J 1950; 2: 739-748.

28. Doll R, Hill AB. The mortality of doctors in relation to their smoking habits; a preliminary report. Br Med J 1954; 4877: 1451-1455.

29. Lalonde M. A new perspective on the health of Canadians a working document. Ottawa 1974. Available from: http://nccdh.ca/ resources/entry/new-perspective-on-the-health-of-canadians (accessed: 15 May 2019).

30. Mackenbach JP, Kulhanova I, Bopp M, et al. Inequalities in alcohol-related mortality in 17 European countries: a retrospective analysis of mortality registers. PLoS Med 2015; 12: e1001909.

31. McKee M. Cochrane on Communism: the influence of ideology on the search for evidence. Int J Epidemiol 2007; 36: 269-273.

32. Moskalewicz J, Wieczorek Ł. Dostępność, konsumpcja alkoholu i konsekwencje picia - trzy dekady doświadczeń [Affordability and availability, alcohol consumption and consequences of drinking three decades of experiences]. Alkoholizm i Narkomania 2009; 22: 305-337.

33. Popova S, Rehm J, Patra J, Zatoński W. Comparing alcohol consumption in central and eastern Europe to other European countries. Alcohol Alcohol 2007; 42: 465-473.

34. Rehm J, Sulkowska U, Mańczuk M, Boffetta P, Powles J, Popova S, Zatoński W. Alcohol accounts for a high proportion of premature mortality in central and eastern Europe. Int J Epidemiol 2007; 36 458-467.

35. Keys A, Aravanis C, Buchem FSP, et al. The diet and all-causes death rate in the Seven Countries Study. Lancet 1981; 2: 58-61.

36. Murray CJ, Lopez AD. Global and regional cause-of-death patterns in 1990. Bull World Health Organ 1994; 72: 447-480.

37. Rehm J, Zatoński W, Taylor B, Anderson P. Epidemiology and alcohol policy in Europe. Addiction 2011; 106 (Suppl 1): 11-19.

38. Traill B, Henson S. The nutritional implications of changing food systems in eastern Europe. Proc Nutr Soc 1991; 50: 703-718.
39. Zatoński WA, Sulkowska U, Mańczuk M, et al. Liver cirrhosis mortality in Europe, with special attention to Central and Eastern Europe. Eur Addict Res 2010; 16: 193-201.

40. Zatoński WA. Report of the task group "III health prevention and treatment". To examine issues relevant to and reflecting the diversity of country contexts within the WHO European Region (e.g. from countries in the Central Asian sub-region to countries in the Central and Eastern European region etc.). Synopsis and recommendations. European Review of health Inequalities.

41. Feachem R. Health decline in Eastern Europe. Nature 1994; 367: 313-314

42. Unal B, Critchley JA, Capewell S. Explaining the decline in coronary heart disease mortality in England and Wales between 1981 and 2000. Circulation 2004; 109: 1101-1107.

43. Zatoński WA, Mańczuk M. Co zagraża zdrowiu Polek i Polaków? Czy zagrożenie nowotworami w Polsce rośnie? In: Wybrane problemy onkologii. Towpik E (ed.). Wydawnictwo Domena, Warszawa $2015 ; 18-23$.

44. Zatoński WA, Sulkowska U, Janik-Koncewicz K, Mańczuk M, Zatoński M. Report of "To examine issues relevant to and reflecting the diversity of country contexts within the WHO European Region". European Review of Health Inequalities. The task group "ill health prevention and treatment".

45. CBOS. Zadowolenie z życia. Komunikat z badań. Nr 6/2019. Available from: https://www.cbos.pl/SPISKOM.POL/2019/ K_006_19.PDF (accessed: 15 May 2019).

46. Janik-Koncewicz K, Herbeć A, Zatoński M, Rosik K, Młoźniak I, Krajewski J, Wójcik I, Rosińczuk J, Szuba A, Zatoński WA. Building health literacy in a Polish region: protocol for the POWER project in Lower Silesia. J Health Inequal 2018; 4: 27-30.

47. Marmot M, Friel S, Bell R, et al.; Commission on Social Determinants of Health. Closing the gap in a generation: health equity through action on the social determinants of health. Lancet 2008; 372: 1661-1669.

48. Matthes BK, Zatoński M. Tobacco control and sustainable development: shared challenges and future opportunities. J Health Inequal 2019; 5: 71-79.

49. Aaro LE. Eea and Norway Grants - reducing social and economic disparities in Europe. J Health Inequal 2017; 3: 3-4.

50. Schuz J, Espina C, Villain P, Herrero R, Leon ME, Minozzi S, Romieu I, Segnan N, Wardle J, Wiseman M, Belardelli F, Bettcher D, Cavalli F, Galea G, Lenoir G, Martin-Moreno JM, Nicula FA, Olsen JH, Patnick J, Primic-Zakelj M, Pekka Puska P, van Leeuwen FE, Wiestler O, Zatoński W, Working Groups of Scientific Experts. European Code against Cancer 4th Edition: 12 ways to reduce your cancer risk. Cancer Epidemiol 2015; 39 (Suppl 1): 1-10.

51. Zatoński W, Sulkowska U, Przewoźniak K. Epidemiologia nowotworów złośliwych w Polsce. Główny Urząd Statystyczny, Rządowa Rada Ludnościowa 2014; 30-49.

52. Zatoński WA, Tukiendorf A and HPF team. Lung cancer mortality decline among middle-aged men and women in Poland and the UK. J Health Inequal 2017; 3: 123-126.

53. Zatoński WA, Zatoński M, Janik-Koncewicz K, et al. Hundred years of cigarette smoking in Poland: three phases of the tobacco epidemic. J Health Inequal 2017; 3: 118-122. 
54. Zatoński WA, Zatoński M. Poland’s rapid lung cancer decline in the years 1990-2016. The first step towards the eradication of lung cancer in Poland. Health Prob Civil 2017; 11: 211-225.

55. Zatoński W, Sulkowska U, Zatoński M, et al. Alcohol taxation and premature mortality in Europe [Letter to the editor]. Lancet 2015; 385: 1181.

56. Drope J, Stoklosa M. Report from the WHO FCTC Seventh Session of the Conference of Parties. J Health Inequal 2016; 2: 128-129.

57. GBD 2015 Tobacco Collaborators. Smoking prevalence and attributeable disease burden in 195 countries and territories, 1990-2015: a systematic analysis from the Global Burden of Disease Study 2015. Lancet 2017; 389: 1885-1906.

58. Hoffman SJ, Mammone J, Rogers Van Katwyk S, et al. Cigarette consumption estimates for 71 countries from 1970 to 2015: systematic collection of comparable data to facilitate quasi-experimental evaluations of national and global tobacco control interventions. BMJ 2019; 19: 12231.

59. Ng M, Freeman MK, Fleming TD, Robinson M, et al. Smoking prevalence and cigarette consumption in 187 countries, 19802012. JAMA 2014; 311: 183-192.

60. Pikala M, Maniecka-Bryła I. Fifteen-year mortality trends in Poland analysed with the use of standard expected years of life lost, 2000-2014. Sci Rep 2017; 7: 8730.

61. Ordinance of the Minister of Finance of 01.08.2002, no. 1065.

62. Świątkiewicz G, Wieczorek $€$, Allamani A. What influences changes in alcoholic beverage consumption over time? Poland in the light of the European Union Amphora Study. Subst Use Misuse 2014; 49: 1601-1610

63. Zatoński WA, Młoźniak I, Zatoński M, Gruszczyński Ł. Small bottles - huge problem? A new phase of Poland's ongoing alcohol epidemic. J Health Inequal 2019; 5: 86-88.

64. Bagnardi V, Zatonski W, Scotti L, et al. Does drinking pattern modify the effect of alcohol on the risk of coronary heart disease? Evidence from a meta-analysis. J Epidemiol Community Health 2008; 62: 615-619.

65. Kristen M. Fedak, Autumn Bernal, Zachary A. Capshaw, Sherilyn Gross. Applying the Bradford Hill criteria in the 21st century: how data integration has changed causal inference in molecular epidemiology. Emerg Themes Epidemiol 2015; 12: 14.

66. Moskalewicz J. Evolution of alcohol policy in Poland during the transition period. J Health Inequal 2019; 5: 41.

67. Gerry C, Raskina Y, Tsyplakova D. Convergence or givergence? Life expectancy patterns in post-comunist countries, 19592010. Social Indicators Research: An International and Interdyscyplinary Journal for Quality-off-Life Measurement 2018; 140: 309-332.

68. Karanikolos M, Adany R, McKee M. The epidemiological transition in Eastern and Western Europe: a historic natural experiment. Eur J Public Health 2017; 27: 4-8.

69. Rehm J, Probst C. Decreases of life expectancy despite decreases in non-communicable disease mortality: the role of substance use and socioeconomic status. Eur Addict Res 2018; 24: 53-59.

70. Rehm J, Stelemekas M, Badaras R. Research protocol to evaluate the effects of alcohol policy changes in Lithuania. Alcohol Alcohol 2019; 54: 112-118.
71. Act of 27 April 2001 regarding Upbringing in Sobriety and Countering Alcoholism, the Broadcasting Act, and the Stamp Duty Act. Available from: http://www.parpa.pl/download/ustawaang.pdf (accessed: 15 May 2019).

72. Synergion. Where is the little vodka flowing? Report on the little vodka' market and the changes it causes in consumer behaviour. Available from: https://www.slideshare.net/synergion/synergionraport-dokad-plynie-mala-wodka-2019 (accessed: 15 May 2019). 